\title{
Dental Caries among Tasters and Non-Tasters of PTC Substance in Students of Qurna Population
}

\author{
Hasna Amir Mohaus ${ }^{1}$ \\ ${ }^{1}$ College of Education in Qurna, Biology Department, University of Basrah, Basrah, Iraq \\ Correspondence: Hasna Amir Mohaus, College of Education in Qurna, Biology Department, University of \\ Basrah, Basrah, Iraq. E-mail: waleed.kassim95@gmail.com
}

Received: April 7, 2019

doi:10.5539/jmbr.v9n1p82
Accepted: June 1, 2019

Online Published: October 23, 2019

\begin{abstract}
Objective: Dental caries is one of the most common diseases found in human populations and it is still prevalent and widespread in all around the world. newer strategies emphasize disease prevention as a model of disease management. For early detection and monitoring of caries rather than treatment Taste has valuable roles in our lives in health and disease. genetic markers such as PTC substance taste ability may represent a useful tool to predict the susceptibility to caries. This study aims to investigate the relationship between the taste ability of phenylthiocarbamide (PTC) substance and dental caries.
\end{abstract}

Materials and Methods: The current study was conducted from November 2017 to April 2018 in Qurna and Madiana population/Basrah/Iraq, PTC taste sensitivity was determined among random sample of (406) student from primary and secondary schools; 216 males and 190 females, their ages ranging from (6-17) years old. For dental caries assessment, dmft/DMFT scores were recorded. Individuals were divided into three groups (low, high and very high) according to their dental caries severity in addition to the free caries individuals.

Results: The proportion of tasters were higher as compared to non-tasters in this sample. The results showed an increase in the prevalence of caries among primary $(68 \%)$ and secondary $(57.6 \%)$ school's students respectively and for both of them $(64.03 \%)$. In primary school; females had an elevated percentage of caries $(73.1 \%)$ compared to their counterpart males $(65 \%)$. The results of this study did not show a significant relationship between the taste of PTC substance and dental caries, with equal proportions of caries prevalence among tasters and non-tasters $(\mathrm{P}>0.05)$. However, the results showed significant differences in age effect in the prevalence of dental caries among primary and secondary students as it increased in individuals of the age group (6-12) years compared to the age group (13-17) years.

Conclusion: The results of this study did not show a significant relationship between the taste of PTC substance and dental caries. In other hand age have a significant influence especially in primary age school and females were more affected than males. The appearance of the two phenotypes of PTC taste may be due to the involvement of other genes, rather than the PTC gene only, including CA6 gene and its variation, which in turn affects the $\mathrm{pH}$ capacity of the saliva, a factor associated with tooth decay. Due to the multifactorial nature of dental caries, the individual's vulnerability may differ from one to another. In addition, particularly regarding diet, part of the strategy to be adopted can be defined as health promotion by preventing the occurrence of the disease rather than treatment. Integrating a healthy dietary regimen into the daily routine can have a real influence on oral health and can be regarded as a primary step towards caries prevention. future research efforts should continue to emphasize early detection and caries prevention strategies.

Keywords: PTC Sensitivity, Taste, Dental Caries, Tasters, Basrah/Qurna Population, dmft/DMFT

\section{Introduction}

Taste is divided into four main senses: salty, sweet, sour and bitter. A fifth called umami (meaty or delicious) and sixth type also had been found for tasting amino acids and fatty acid texture respectively (Chaudhari \& Roper, 2010; Ebba et al., 2012; Melis et al., 2018). Taste has a valuable role in our lives. All types of taste have significant roles for living and survival; in health and disease. Bitter taste has gained special developmental importance; it has contributed to human survival by warning it from ingesting toxins (usually have a bitter taste), which are widely dispersed by nature in plants or in others (Wooding et al., 2004; Sandell \& Breslin, 2006; 
Newcomb, 2012).

Receptors of bitter taste had a great variation (about 25 genes) which indicates their importance in sensing multiple types of materials that are biologically important (Viswanathan, 2013; Farquhar et al., 2015; Verbeurgt et al., 2017). Discovering the presence of many bitter taste receptors in extra oral cavity in some organs and glands (Clark, 2014; Wölfle et al., 2015; Lu et al., 2017; Tan et al., 2018); confirmed their important biological roles in digestion, food metabolism and in the prevention of certain diseases (Dotson et al., 2010; Campa et al., 2012; Newcomb et al., 2012; Choi, 2014; Lu et al., 2017).

The ability or inability to taste the bitterness of the phenyl thiocarbamide (PTC) substance is one of the most important genetic markers that study human evolution and adaptation to different environments, as well as to study its effect on dietary habits associated with some important food-related diseases (Shivaprasad et al., 2012; Campbell et al., 2013; Tepper et al., 2014; Choi, 2014; Shen et al., 2016; Tepper et al., 2017; Yamaki et al., 2017).

Depending on the phenotypic pattern of PTC tasting, humans were divided into two main groups, either tasters or non-tasters. These patterns were inherited as a simple Mendelian trait with two alleles one of them $(\mathrm{T})$ have a complete dominance over the other (t) (Fox, 1932; Blackslee \& Fox, 1932). There was a gradual quantitative variation in the sensitivity of tasting this substance. According to this variation individuals were classified as; super tasters, medium tasters and non-tasters (Bartoshuk et al., 1994). At the molecular level, the inheritance of this trait was found to be due the presence of a major locus gene called TAS2R38 (TAS = TASTE, Family = 2, R $=$ receptors, Member: 38)., which is responsible for the taste of PTC and a number of other similar substances (containing N-C=S moiety such as 6-n-Propylthiouracil (Prop)) (Kim et al., 2003). Two major common forms of haplotypes were detected: PAV for tasting and AVI for not tasting. With a number of intermediate and rare patterns found in some population (Campbell et al., 2012; Wooding et al., 2006).

The inherited sensitivity of tasting PTC and similar substances may contribute to the observed variability of individuals in their food intake habits and dietary behavior toward some types of fruits and vegetables (Dotson et al., 2010; Drewnowski et al., 2001; Shen et al., 2016). Consequently, these differences will impact their susceptibility of infection with some important related - food diseases of human (Timpson et al., 2005; Dotson et al., 2008; Turner-McGrievy et al., 2013; Choi, 2014).

Many researchers had studied the relationship of this trait with some diseases (Timpson et al., 2005; Shivaprasad et al., 2012; Choi, 2014; Shafaie et al., 2015; Yamaki et al., 2017; Burgess et al., 2017; Yildiz et al., 2016), including dental caries disease.

Dental caries is a multifactorial disease represents one of the major public health problems (WHO, 2017). It is caused by a combination of different genetic, as well as environmental factors (Opal et al., 2015; Yildiz et al., 2016; Lips et al., 2017; Weber et al., 2018). Many genes may influence the development of the risk of the disease (Shimizu et al., 2012; Renuka et al., 2013; Ergoz et al., 2014; Opal et al., 2015; Duverger et al., 2014; Morrison et al., 2016; Kong et al., 2017).

Some studies have suggested that there may be a relationship between the phenotypic patterns of PTC tasting and tooth decay, especially among children in the school age (Chung, 1963; Rupesh \& Nayak, 2006) and this trait could be used as a sign of early childhood caries (ECC) diagnosis (Furquim et al., 2010; Hedge \& Sharma, 2008). At the molecular level, this relationship had been studied (Wendell et al., 2010); the results showed that people with the genotype AVI may be more likely to develop tooth decay than the PAVs who may be more protected. Some subsequent studies on the basis of molecular analysis failed to confirm this association (Weber, 2016; Weber et al., 2018)

Different immunity response had been found among different types of both genotypes of tas2r38 (PAV, AVI) against bacteria causes respiratory infections (Lee \& Cohen, 2013; Lee \& Cohen, 2014; Adappa et al., 2016; Lu et al., 2017) and cariogenic bacteria (Gil et al., 2015), which opened a new era to the potential for the pathogenic-related biological functions of this trait (Viswanathan, 2013; Verbeurgt et al., 2017).

The current study aims at finding out the relationship between the taste of PTC with a genetic basis and tooth decay in a sample of primary and secondary students in Qurna and Madiana population, north of Basrah/Iraq.

\section{Materials and Methods}

\subsection{The Studied Sample}

The study was conducted in the city of Qurna and Madiana north of Basrah/Iraq on a sample of (406) individuals of the primary and secondary school's students from both sexes' males and females; ages ranged between (6-17) 
years old.The sample was divided into two age groups: primary (6-12) y and secondary education (13-17) y.

\subsection{Dental Caries Assessment}

For caries diagnosis; DMFT (Number of decayed, missed, filled tooth) incidence were used (WHO; Mulic et al., 2012; Sovik et al., 2014). The severity of caries was counted into three sections: low, high and very high depending on the number of the observed dmft/DMFT: (1-3), (4-6) and 7 or more respectively (Weber, 2016; Feng et al., 2014). We excluded all teeth losing for any other reason than caries (WHO, 2003).

\subsection{Measurement of PTC Taste Sensitivity}

\subsubsection{PTC Sensitivity Test Papers}

Thirteen graduated concentrations of PTC were prepared by dissolving $0.13 \mathrm{~g}$ of this substance in $100 \mathrm{ml}$ of boiling distilled water to prepare Solution No.1, which is the highest concentration, followed by a series of gradual dilutions until solution No.13 (Harris \& Kalmus, 1949). Filter papers impregnated in each concentration numbered (1-13) and the boiling water as a control. The filters were lifted to be fully saturated; then dried and cut into small pieces, after their drying it was used to measure the sensitivity of tasting PTC substance (Ashly, 1960).

\subsubsection{PTC Taste Sensitivity Test}

The threshold score for PTC taste sensitivity was determined by; first asking every individual to wash his/her mouth with fresh water to avoid any prior bitter or other taste, Then, he/she started to taste filter paper as a control followed by PTC test paper and so on begging from the lowest concentrations grade No.13 up to the next higher concentration and so on towards the highest concentration (sol. No.1); till the individual felt bitterness, This degree of PTC sensitivity was recorded as his/her threshold No. The individuals who did not taste all the solutions up to (sol. No.1) were considered as having (0) score.

\subsubsection{Phenotypic Classes of PTC Tasting}

Phenotypic class of PTC tasting trait were determined depending on the critical binomial distribution. The anti-mode point was used to the classification of individual as tasters or non-tasters (Bartoshuk et al., 1994; Omari, 1986).

\subsection{Statistical Analysis}

The frequency of each PTC phenotypic class was calculated. The chi-square test was used to determine significant differences between different classes and groups. $\mathrm{P}$ value 0.05 was assigned as a significant level. Statistical packages IBM SPSS (version 22, 2013) was used for all statistical analysis.

\section{Results}

Table 1; Figure 1 shows the proportion of tasters and non-tasters in the primary stage. The percentage of tasters' phenotype (82.6\%) (66.6\%), increased as compared to non-tasters (17.3) (33.3) among males and females respectively. Statistical analysis showed significant differences between the two gender $(\mathrm{p} \leq 0.05)$.

In general, the proportions of tasters and non-tasters among the total number of primary school students were $(74.4 \%)(25.6 \%)$ respectively.

Table 1. Proportions of PTC tasters and non-tasters among males and females students of primary school

\begin{tabular}{llllll}
\hline Gender * & Total No. & No. & $\begin{array}{c}\text { Tasters } \\
\text { Percent } \%\end{array}$ & No. & $\begin{array}{l}\text { Non-tasters } \\
\text { Percent } \%\end{array}$ \\
\hline Males & 121 & 100 & 82.6 & 21 & 17.3 \\
Females & 129 & 86 & 66.6 & 43 & 33.3 \\
Total & 250 & 186 & 74.4 & 64 & 25.6 \\
\hline
\end{tabular}

- Significance $\left[\left(x^{2}=10.16 \mathrm{df}=1,(\mathrm{p} \leq 0.05)\right]\right.$ 


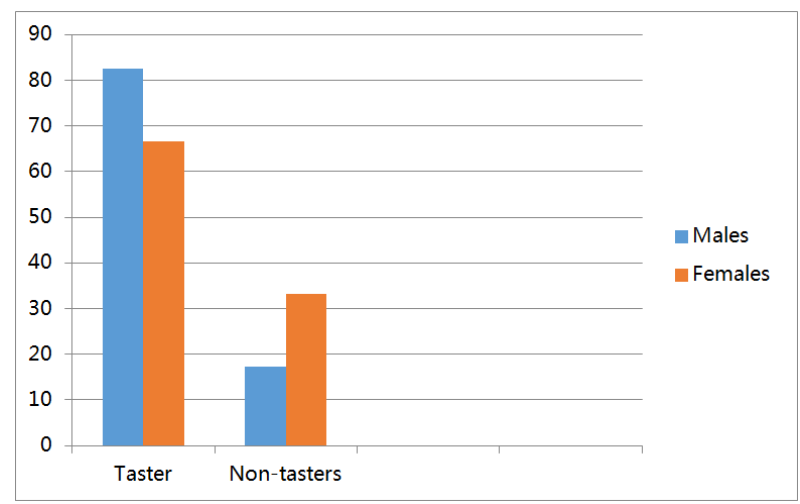

Figure 1. Proportions of PTC tasters and non-tasters among males and females' students of primary school

Regardless of PTC tasting status (tasters or non-tasters); caries as compared to non-caries individuals recorded a high prevalence of caries in primary school's students among both: males (65.2) (Table 2) and females (70.5) (Table 3) respectively. females were more susceptible to have caries than males. However, this elevation had no significant power. According to PTC tasting phenotypes and caries prevalence; statistical analysis showed no significant differences $(\mathrm{p}>0.05)$ between tasters (65) (72.1) and non-tasters (66.6) (67.4) from both males and females respectively.

Table 2. Prevalence of caries among tasters and non-tasters of PTC substance in primary school's students/males

\begin{tabular}{|c|c|c|c|c|c|}
\hline \multirow{2}{*}{ Phenotype* } & \multirow{2}{*}{ Total No. } & \multicolumn{3}{|c|}{ Caries (dmft/DMFT) } & \multirow{2}{*}{$\begin{array}{l}\text { No-caries } \\
\text { Percent \% }\end{array}$} \\
\hline & & No. & Percent \% & No. & \\
\hline Non-tasters & 21 & 14 & 66.6 & 7 & 33.3 \\
\hline Tasters & 100 & 65 & 65 & 35 & 35 \\
\hline Total & 121 & 79 & 65.28 & 42 & 43.72 \\
\hline
\end{tabular}

*not significance $\left[\left(x^{2}=0.0126 \mathrm{df}=1,(\mathrm{p}>0.05)\right]\right.$

Table 3. Prevalence of caries among tasters and non-tasters of PTC substance in primary school's students/females

\begin{tabular}{lllll}
\hline Phenotype* & Total No. & No. & Caries (dmft/DMF) & \multicolumn{2}{c}{ No-caries } \\
Percent $\%$
\end{tabular}

* not significance $\left[\left(x^{2}=0.308 \mathrm{df}=1,(\mathrm{p}>0.05)\right]\right.$

A comparison of caries severity among tasters and non-tasters of PTC substance in primary school students from both sexes; males (Table 4) and females (Table 5) revealed a different mode of caries severity distribution among tasters and non-tasters from both sexes; it seems that the gender may have an effect on the relation of PTC tasting and caries severity; Non tasters males seems to be more susceptible to infect by low caries severity $(85.7 \%)$ as compared to tasters $(67.6 \%)$ with no significance differences $(\mathrm{p}>0.05)$; while the opposite were recorded in females ; Tasters had a high proportion of low caries severity $(80.64 \%)$ as compared to non-tasters $(58.6 \%)$. These differences were very close to be statistically significant $\left[\left(x^{2}=5.133 \mathrm{df}=2,(0.10>\mathrm{p}<0.05)\right]\right.$.

As a total; PTC tasters and non-tasters of PTC substance in primary school's students had no significance differences $((\mathrm{p}>0.05))$ between them according to their caries severity distribution (Table 6$)$. 
Table 4. Caries severity among tasters and non-tasters of PTC substance in primary school's students/males

\begin{tabular}{lllll}
\hline \multirow{2}{*}{ Phenotype } & Total No. & Low (1-3) tooth & Caries'severity (dmft/DMF) No. (\%) & Very high 7 $\geq$ \\
\hline Non-tasters & 14 & $12(85.7)$ & High (4-6) tooth & $0(0)$ \\
Tasters & 65 & $44(67.6)$ & $16(14.2)$ & $5(100)$ \\
Total & 79 & $56(78.8)$ & $18(22.7)$ & $5(6.3)$ \\
\hline
\end{tabular}

*Non-significance $\left[\left(x^{2}=1.99 \mathrm{df}=2,(\mathrm{p}>0.05)\right]\right.$

Table 5. Caries severity among tasters and non-tasters of PTC substance in primary school's students/females

\begin{tabular}{lllcl}
\hline \multirow{2}{*}{ *Phenotype } & Total No. & Low (1-3) tooth & Caries severity (dmft/DMF) No. (\%) & Very high 7 $\geq$ \\
\hline Non-tasters & 29 & $17(58.6)$ & High (4-6) tooth & $2(6.8)$ \\
Tasters & 62 & $50(80.6)$ & $10(34.4)$ & $2(3.2)$ \\
Total & 91 & $67(73.6)$ & $20(21.9)$ & $4(4.3)$ \\
\hline
\end{tabular}

- $\left[\left(\mathrm{x}^{2}=5.133 \mathrm{df}=2,(0.10>\mathrm{p}<0.05)\right]\right.$.

Table 6. Caries severity among tasters and non-tasters of PTC substance in primary school's students/females \& males

\begin{tabular}{lllcl}
\hline \multirow{2}{*}{ *Phenotype } & \multirow{2}{*}{ Total No. } & Low (1-3) tooth & Caries severity (dmft/DMF) No. (\%) \\
& & $29(58.6)$ & $12(24.8)$ & Very high $7 \geq$ \\
\hline Non-tasters & 43 & $94(55.2)$ & $26(29.4)$ & $7(6.8)$ \\
Tasters & 127 & $123(72.3)$ & $38(22.3)$ & $9(5.3)$ \\
Total & 170 & & \\
\hline
\end{tabular}

*Not significance $\left[\left(x^{2}=1.008 \mathrm{df}=2,(\mathrm{p}>0.05)\right]\right.$

Table 7. Prevalence of caries among tasters and non-tasters of PTC substance among secondary school's students/females \& males

\begin{tabular}{lllcc}
\hline *Phenotype & Total No. & \multicolumn{2}{c}{ Caries (DMFT) } & No-caries \\
& & No. & No. & 26 \\
Non-tasters & 54 & 28 & 51.8 & 48.2 \\
Tasters & 102 & 62 & 60.7 & 40 \\
Total & 156 & 90 & 57.6 & 66 \\
\hline
\end{tabular}

*not significance $\left[\left(x^{2}=1.151 \mathrm{df}=1,(\mathrm{p}>0.05)\right]\right.$

At secondary stage; students had also a high prevalence of caries (57.6) (Table 7). There were no significant differences between males and females according to their PTC tasting status ( $p>0.05)$. However, the results of this sample showed that there was a significance difference in the prevalence of caries between the primary and secondary students according to their ages; as it increased at the age group (6-12) years of primary school compared to the age group (13-17)years of the secondary school's students (Table 8).

Table 8. Comparison of caries prevalence among primary and secondary students

\begin{tabular}{|c|c|c|c|c|c|}
\hline \multirow{2}{*}{ Age group(y) } & \multirow{2}{*}{ Total No. } & \multicolumn{2}{|c|}{ Caries } & \multicolumn{2}{|c|}{ No-caries* } \\
\hline & & No. & $\%$ & No. & $\%$ \\
\hline $6-12$ & 250 & 170 & 68 & 80 & 32 \\
\hline $13-17$ & 156 & 90 & 57.6 & 66 & 42.3 \\
\hline Total & 406 & 260 & 64.03 & 146 & 36.4 \\
\hline
\end{tabular}

* Significance $\left[\left(x^{2}=4.616 \mathrm{df}=1,(\mathrm{p} \leq 0.05)\right]\right.$ 


\section{Discussion}

Dental caries refers to dental decomposition and is the result of long-term exposure to a low acidity arising from the fermentation of carbohydrates found in the mouth by several types of bacteria. Caries can influence our quality of life and nutrition (Peres et al., 2016).

Tooth decay is a complex disease with multiple causes and is still prevalent in all countries of the world despite the use of many preventive applications (WHO, 2003).

No correlation was found between PTC taste perception phenotypes (tasters and non-tasters) and dental caries among school children of primary and secondary school's students in Qurna and Madaina population/Basrah/Iraq. The PTC taste perception may have an effect on dental severity in females while no such effect was found in males.

Tooth decay is a major global health problem and is estimated to affect or affect about $60-90 \%$ of school children and many adults (Weber, 2016; Dye et al., 2015). The causes of tooth decay in children appear to be different from those in the permanent teeth of adults (Wang et al., 2010). and women are more likely to be infected than men (Ferraro \& Vieira, 2010; WHO, 2003). The level of caries is higher for the primary dentition than the permanent dentition for children of several developing countries in Asia and Africa (WHO, 2017). It is possible that the association of TAS2R 38 with caries in the primary dentition may reflect biological processes that change with age, a greater influence of social and cultural influences on adult habits, or a combination of both, and could be explained by age-related processes (Wendell et al., 2010).

Recent studies have shown that human caries is a multifactorial disease and that there were many genes that may share the rate of infection, some of these, were directly related to the formation of teeth while others are not (Shuler, 2001; Shaffer, 2011; Shaffer, 2013; Renuka et al., 2013; Abbasoğlu et al., 2015; Kong et al., 2017; Weber et al., 2018).

The results of the current study indicate that there was a significant difference in the prevalence of tooth decay according to the age and gender; children aged 6-12 were the most vulnerable to infect with this disease while females were more infected than males. Many environmental factors as well genetic factors may play a role in these differences; Perhaps the most important reason is that children of primary age were more prone to eat sweets and sugars, and their teeth are weak and will prone to decay (Anilker et al., 1991; Drewnowski et al., 2001; Abbasoğlu et al., 2015). In the other hand secondary school's students might have an increase in health awareness and be more attention to oral hygiene; also eating sweets in secondary ages is less than in primary ages, or their immunity system is mature and more effective than in childhood; Besides expression of some genes may differ between these two ages (Wang et al., 010) or could be by all the mentioned above. Differences in hormonal constitution, immunity response could explain the variation of caries infection in both gender where females seem to be more affected than males (Lukacs, 2007; Ferraro \& Vieira, 2010; Lukacs, 2011; Loper et al., 2015; Joseph et al., 2016)

Dental caries thought to be a dietary-related disease, children's dietary habits largely influence their risk of developing caries. Children are thought to like sweets more than adults and a high preference of sugar among children has been reported (Drewnowski, 2000; Mennella \& Bobowski, 2015).

Many researches recorded a correlation of PTC sensitivity with some foods and other sensation of: sweet, salty bitter taste (Akella et al., 1998; Anilker et al., 1991; Keller et al., 2002; Keller et al., 2014; Joseph et al., 2016).

Some studies indicate that non-tasters were more likely to have tooth decay than those who were tasters (Furquim et al., 2010; Pidamale, 2012), Chung (1965) noted this relationship between pre-school and non-adult age groups. Wendell et al. (1990) found that AVI/AVI genotype have been more susceptible to have caries and explained this by food habits and food preferences, which in turn will affect the development or prevention of the emergence of tooth decay. Yildiz et al. (2016) found that many environment and genetic factors including TAS2R38 (A49P), and CA6 (T55M) gene polymorphism, interact with each other and explained a total of $87.8 \%$ of the variations in DMFT scores in Turkish adults. However, this relation with PTC tasting trait or its association with certain age groups and not with others (Shaffer et al., 2013) is still controversial since some studies confirm it while others were not (Weber, 2016; Weber et al., 2018; Yildiz et al., 2016).

Molecular studies have shown a difference in the immunity response of both tasters and non-tasters to different types of cariogenic bacteria (Gil et al., 2015) and others (Farquhar et al., 2015; Verbeurgt et al., 2017). There are a variety of variations in genes associated with a high or low incidence of tooth decay (Piekoszewska-Ziętek et al., 2017); Thus, Dental caries is a multi-factorial disease and cannot be limited to only one factor or gene (Weber, 2016). The current study, although not confirm this relation in this sample, suggests that the presence or 
compatibility of a number of environmental and genetic factors may shape this association, including a variety of genes, for example, it was found that the heterozygote genotypes of TAS $2 R 38$ gene were associated with certain genetic patterns of CA6-encoded carbonic anhydrase 6; an enzyme important in regulating pH capacity of saliva, which in turn affects the degree of tooth consistency and non-erosion when saliva buffer capacity is low (Li et al., 2015; Melis et al., 2018; Esberg et al., 2019) So, the genetic makeup of an individual from many genes and differences in expression of these genes may affect this relation or explain it.

\section{Conclusion}

In conclusion caries is more complicated disease than it appears and that the subject still needs many of the future studies. These studies included all the consensus of what has been proven impact. In addition, the appearance of the two phenotypes of PTC taste may be due to the involvement of other genes, not only the appearance of the PTC gene, including CA6 gene (Yildiz et al., 2016; Melis et al., 2018), which in turn affects the $\mathrm{pH}$ capacity of the saliva, a factor associated with tooth decay (Esberg et al., 2019). Due to the multifactorial nature of dental caries, the individual's vulnerability may differ from one another where some may be more susceptible to a higher risk of developing the disease. In addition, particularly regarding diet, part of the strategy to be adopted can be defined as health promotion by preventing the occurrence of the disease rather than treatment. Integrating a healthy dietary regimen into the daily routine can have a real influence on oral health and can be regarded as a primary step towards caries prevention.

\section{Acknowledgements}

I would like to thank Professor Dr. Asaad Y. Ayied, College of agriculture/Basrah University for his great assistance and help in writing and data analyzing. Also, my great thanks to my ex colleagues Dr. Ibtissam Kareem and Dr. Afrah/college of dentistry/Misssan University for their support and help in laboratory preparations.

\section{Conflict of interests}

The authors declare that there is no conflict of interests regarding the publication of this paper.

\section{References}

Abbasoğlu, Z., Tanboğa, İ., Küchler, E. C., Deeley, K., ..., \& Vieira, A. R. (2015). Early childhood caries is associated with genetic variants in enamel formation and immune response genes. Caries Res, 49, 70-77.

Adappa, N. D., Truesdale, C. M., Workman, A. D., Doghramji, L., ..., \& Cohen, N. A. (2016). Correlation of T2R38 taste phenotype and in vitro biofilm formation from nonpolypoid chronic rhinosinusitis patients. Int Forum Allergy Rhinol., 6, 783-791.

Akella, G. D., Henderson, S. A., \& Drewnowski, A. (1998). Sensory acceptance of Japanese green tea and soy products is linked to Genetic sensitivity to 6-propylthiouracil. Nutr. cancer, 29, 146-151.

Anilker, J. A., Bartoshuk, L., Ferris, A. M., \& Hooks, L. D. (1991). Children's food preferences and genetic sensitivity to the bitter taste of 6-n-propylthiouracil (PROP). Am J Clin Nutr., 54, 316-20.

Ashly, M. M. (1960). An introduction to physical Anthropology (3rd ed.). Charles C. T, Illinois.

Bartoshuk, L. M., Duffy, V. B., \& Miller, I. J. (1994). PTC/PROP tasting: Anatomy, psychophysics, and sex effects. Physiol Behav., 56, 1165-1171.

Bartoshuk, L. M., Duffy, V. B., Fast, K., Green, B. G., \& Snyder, D. J. (2003). Hormones, age, genes and pathology: How do we assessment variation in sensation and preference? Chem. Senses, 28, 173-186.

Blakeslee, A. F., \& Fox, A. L. (1932). Our different taste worlds: PTC as a demonstration of genetic differences in taste. J Hered., 23, 96-107.

Burgess, B., Raynor, H. A., \& Tepper, B. J. (2017). PROP Non taster Women Lose More Weight Following a Low-Carbohydrate versus a Low-Fat Diet in a Randomized Controlled Trial. Obesity, 25, 1682-1690.

Campa, D., D Rango, F., Carrai, M., Crocco, P., Montesanto, A., \& Canzian, F. (2012). Bitter Taste Receptor Polymorphisms and Human Aging. PLoS ONE, 7(11), e45232.

Campbell et al. (2012). Evolution of functionally diverse alleles associated with PTC bitter taste sensitivity in Africa. Mol Biol Evol., 29, 1141-1153.

Chaudhari, N., \& Roper, S. D. (2010). The cell biology of taste. J Cell Biol., 190, 285-296.

Choi, S. E. (2014). Racial differences between African Americans and Asian Americans in the effect of 6-n-propylthiouracil taste intensity and food liking on body mass index. J Acad Nutr Diet., 114, 938-944. 
Chung, C. S., Witkop, C. J. Jr., Wolf, R. O., \& Brown, K. S. (1965). Dental caries in relation to PTC taste sensitivity, secretor status, and salivary thiocyanate level. Arch Oral Biol., 10, 645-653.

Clark, A. A. (2014). Bitter Taste Receptor Expression and Function in the Thyroid. Ph D. Thesis, University of Maryland Baltimore. USA.

Dinehart, M. E., Hayes, J. E., Bartoshuk, L. M., Lanier, S. L., \& Duffy, V. B. (2006). Bitter taste markers explain variability in vegetable sweetness, bitterness, and intake. Physiol Behav., 87, 304-313.

Dotson, C. D., Shaw, H. L., Mitchell, B. D., Munger, S. D., \& Steinle, N. I. (2010). Variation in the gene TAS2R38 is associated with the eating behavior disinhibition in Old Order Amish women. Appetite, 54(1), 93-99.

Dotson, C. D., Zhang, L., Xu, H., Shin, Y. K., ..., \& Munger, S. D. (2008). Bitter taste receptors influence glucose homeostasis. PLoS ONE, 3, e3974.

Drewnowski, A. (2000). Sensory control of energy density at different life stages. Proc Nutr Soc., 59, 239-244.

Drewnowski, A., Henderson, S. A., \& Fornell, A. B. (2001). Genetic taste marker and food preferences. Drug Metob Dis, 29, 535-538.

Duffy, V. B., Davidson, A. C., Kidd, J. R., Kidd, K. K., ..., \& Bartoshuk, L. M. (2004). Bitter receptor gene (TAS2R38), 6-n-propylthiouracil (PROP) bitterness and alcohol intake. Alcohol Clin Exp Res, 28(11), 1629-37.

Duverger, O., Ohara, T., Shaffer, J. R., Donahue, D., ..., \& Morasso, M. I. (2014). Hair keratin mutations in tooth enamel increase dental decay risk. J Clin Invest., 124, 5219-5224.

Dye, B., Thornton-Evans, G., Li, X., \& Iafolla, T. (2015). Dental caries and tooth loss in adults in the United States, 2011-2012. NCHS Data Brief, (197), 197.

Ebba, S., Abarintos, R. A., Kim, D. G., Tiyouh, M., Stull, J. C., Movalia, A., \& Smutzer, G. (2012). The examination of fatty acid taste with edible strips. Physiol. Behav, 106, 579-586.

Ergoz et al. (2014). Genetic variation in Ameloblastin is associated with caries in asthmatic children. Eur. Arch. Paediatr. Dent. Off. J. Eur. Acad. Paediatr. Dent, 15(3), 211-6.

Esberg, A., Hawort, S., Brunius, C., Holgerson, P. L., \& Johansson, I. (2019). Carbonic Anhydrase 6 Gene Variation influences Oral Microbiota Composition and Caries Risk in Swedish adolescents. Sci Rep., 9(1), 452.

Farquhar, D. R., Kovatch, K. J., Palmer, J. N., Shofer, F. S., Adappa, N. D., \& Cohen, N. A. (2015). Phenylthiocarbamide taste sensitivity is associated with sinonasal symptoms in healthy adults. Int Forum Allergy Rhinol, 5(2), 111-118.

Featherstone, J. D. (2008). Dental caries: A dynamic disease process. Aust Dent J, 53(3), 286-91.

Feng et al. (2014). Genome wide association scan for chronic periodontitis implicates novel locus. BMC Oral Health, 14, 84 .

Ferraro, M., \& Vieira, A. R. (2010). Explaining gender differences in caries: A multifactorial approach to a multifactorial disease. Int $J$ Dent, 1-5.

Fox, A. L. (1932). The relationship between chemical constitution and taste. Proc Natl Acad Sci., 18(1), 115-120

Furquim, T. R., Poli-Frederico, R. C., Maciel, S. M., Gonini-Junior, A., \& Walter, L. R. (2010). Sensitivity to bitter and sweet taste perception in schoolchildren and their relation to dental caries. Oral Health Prev. Dent, 8, 253-259.

Gil, S., Coldwell, S., Drury, J. L., Arroyo, F., Phi, T., Saadat, S., Kwong, D., \& Chung, W. (2015). Genotype-specific regulation of oral innate immunity by T2R38 taste receptor. Molecular Immunology, 68(2), 663-670.

Harris, H., \& Kalmus, H. (1949). The measurement of taste sensitivity to (PTC). Ann. Eugen, 15, 2431.

Hedge, A., \& Sharma, A. (2008). Genetic sensitivity to 6-n-propylthiouracil (prop) as a screening tool for obesity and dental caries in children. J Clin Pediatr Dent, 33, 107-112.

Joseph, P. V., Reed, D. R., \& Mennella, J. A. (2016). Individual differences among children in sucrose detection thresholds: Relationship With age, gender, and bitter taste genotype. Nurs Res, 65, 3-12. 
Keller, K. L., Olsen, A., Cravener, T. L., Bloom, R., Chung, W. K., Deng, L., Lanzano, P., \& Meyermann, K. (2014). Bitter taste phenotype and body weight predict children's selection of sweet and savory foods at a palatable test meal. Appetite, 77, 113-121.

Keller, K. L., Steinmann, L., Nurse, R. J., \& Tepper, B. J. (2002). Genetic taste sensitivity to 6-n-propylthiouracil influences food preference and reported intake in preschool children. Appetite, 38, 3-12.

Kim, U. K., Genson, E. J., Coon, H., Leppert, M., Risch, N., \& Drayna, D. (2003). Positional cloning of the human quantitative trait locus underlying taste sensitivity to phenylthiocarbamide. Science, 299, 1221-1225.

Kong, Y. Y., Zheng, J. M., Zhang, W. J., Jiang, Q. Z., Yang, X. C., Yu, M., \& Zeng, S. J. (2017). The relationship between vitamin $\mathrm{D}$ receptor gene polymorphism and deciduous tooth decay in Chinese children. BMC Oral Health, 17(1), 111.

Lee, R. J., \& Cohen, N. A. (2013). The emerging role of the bitter taste receptor T2R38 in upper respiratory infection and chronic rhinosinusitis. Am J Rhinol Allergy, 27(4), 283-6.

Lee, R. J., \& Cohen, N. A. (2014). Sino nasal solitary chemosensory cells "taste" the upper respiratory environment to regulate innate immunity. Am J Rhinol Allergy, 28(5), 366-73.

Li, Z. Q., Hu, X. P., Zhou, J. Y., Xie, X. D., \& Zhang, J. M. (2015). Genetic polymorphisms in the carbonic anhydrase VI gene and dental caries susceptibility. Genet Mol Res, 14, 5986-5993.

Lips, A., Antunes, L. S., Antunes, L. A., Pintor, A. V. B., Santos, D. A. B. D., Bachinski, R., Küchler, E. C., \& Alves, G. G. (2017). Salivary protein polymorphisms and risk of dental caries: A systematic review. Braz Oral Res., 31, e41.

Loper, H. B., Sala, M. L., Dotson, C., \& Steinle, N. (2015). Taste perception, associated hormonal modulation, and nutrient intake. Nutr Rev, 73, 83-91.

Lu, P., Zhang, C. H., Lifshitz, L. M., \& Zhu Ge, R. (2017). Extraoral bitter taste receptors in health and disease. J Gen Physiol., 149(2), 181-197.

Lukacs, J. R. (2007). Sex differences in dental caries in living populations: A global meta-analysis. Am. J. Phys. Anthropol, 160-161.

Lukacs, J. R. (2011). Sex differences in dental caries experience: Clinical evidence, complex etiology. Clin. Oral Investig, 15, 649-656.

Melis, M., Mastinu, M., Arca, M., Crnjar, R., \& Tomassini, B. I. (2018). Effect of chemical interaction between oleic acid and L-Arginine on oral perception, as a function of polymorphisms of CD36 and OBPIIa and genetic ability to taste 6-n-propylthiouracil. PLOS ONE, 13(3), e0194953.

Mennella, J. A., \& Bobowski, N. K. (2015). The sweetness and bitterness of childhood: Insights from basic research on taste preferences. Physiol Behav, 152, 502-507.

Morrison, J., Laurie, C. C., Marazita, M. L., Sanders, A. E., ..., \& Shaffer, J. R. (2016). Genome-wide association study of dental caries in the Hispanic Communities Health Study/Study of Latinos (HCHS/SOL). Hum Mol Genet, 25, 807-816.

Mulic, A., Skudutyte-Rysstad, R., Tveit, A. B., \& Skaare, A. B. (2012). Risk indicators for dental erosive wear among 18-yr-old subjects in Oslo, Norway. Eur. J. Oral Sci, 120, 531-538.

Mulic, A., Tveit, A. B., Wang, N. J., Hove, L. H., Espelid, I., \& Skaare, A. B. (2010). Reliability of two clinical scoring systems for dental Erosive Wear. Caries Res, 44, 294-299.

Murray et al. (2012). Disability-adjusted life years (DALYs) for 291 diseases and injuries in 21 regions, 1990-2010: A systematic analysis for the Global Burden of Disease Study 2010. Lancet, 380(9859), 2197-2223.

Newcomb, R. D., Xia, M. B., \& Reed, D. R. (2012). Heritable differences in chemosensory ability among humans. Flavor, 1, 9.

Omari, Y. I. (1986). Taste deficiency of phenylthiourea in Jordanian population. J Biol Sci Res., 17(1), 253-265.

Opal, S., Garg, S., Jain, J., \& Walia, I. (2015). Genetic factors affecting dental caries risk. Aust Dent J, 60, 2-11.

Peres, M. A., Sheiham, A., Liu, P., Demarco, F. F., ..., \& Peres, K. G. (2016). Sugar consumption and changes in dental caries from childhood to adolescence. $J$ Dent Res., 95, 388-394. 
Pidamale, R., Sowmya, B., Thomas, A., Jose, T., Madhusudan, K. K., \& Prasad, G. (2012). Association between early childhood caries, streptococcus mutans level and genetic sensitivity levels to the bitter taste of, 6-N-propylthiouracil among the children below 71 months of age. Dental Research Journal, 9(6), 730-734.

Piekoszewska-Ziętek, P., Turska-Szybka, A., \& Olczak-Kowalczyk, D. (2017). Single Nucleotide Polymorphism in the A etiology of Caries. Systematic Literature Review Caries Res, 51, 425-435.

Renuka, P., Pushpanjali, K., \& Sangeetha, R. (2013). Review on influence of host genes on dental caries. J Dent Med Sciences, 4 (3), 86-92.

Rupesh, S., \& Nayak, U. A. (2006). Genetic sensitivity to the bitter taste of 6-n propylthiouracil: A new risk determinant for dental caries in children. J Indian Soc Pedod. Prev. Dent., 63-8.

Sandell, M. A., \& Breslin, P. (2006). Variability in a taste-receptor gene determines whether we taste toxins in food. Curr Biol , 16, 792-794.

Shafaie, Y., Hoffman, D. J., \& Tepper, B. J. (2015). Consumption of a high-fat soup preload leads to differences in short-term energy and fat intake between PROP non-taster and super-taster women. Appetite, 89, 196-202.

Shaffer et al. (2011). Genome-wide Association Scan for Childhood Caries Implicates Novel Genes. J. Dent. Res, 90, 1457-1462.

Shaffer, J. R., Feingold, E., Wang, X., Lee, M., ..., \& Marazita, M. L. (2013). GWAS of dental caries patterns in the permanent dentition. $J$ Dent Res, 92, 38-44.

Shen, Y., Kennedy, O. B., \& Methven, L. (2016). Exploring the effects of genotypical and phenotypical variations in bitter taste sensitivity on perception, liking and intake of brassica vegetables in the UK. Food Quality Preference, 50, 71-81.

Shimizu, T., Ho, B., Deeley, K., Briseno-Ruiz, J., ..., \& Vieira, A. R. (2012). Enamel formation genes influence enamel microhardness before and after cariogenic challenge. PLoS One, 7, e45022.

Shivaprasad, H. S., Chiathra, P. T., Kavitha, P., \& Malini, S. S. (2012). Role of phenylthiocarbamide as a genetic marker in predicting the predisposition of disease traits in humans. J Nat Sci Bio Med., 3, 43-47.

Shuler, C. F. (2001). Inherited risks for susceptibility to dental caries. $J$ Dent Educ., 65, 1038-1045.

Sovik, J., Tveit, A. B., Storesund, T., \& Mulic, A. (2014). Dental erosion: A widespread condition nowadays? A cross-sectional study among a group of adolescents in Norway. Acta Odontol Scand., 72, 523-529.

Tepper, B. J. I. D., Melis, M., Koelliker, Y., Gasparini, P., Ahijevych, K. L., \& Iole, T. B. (2017). Factors Influencing the Phenotypic Characterization of the Oral Marker, PROP. Nutrients, 9, 1275.

Tepper, B. J., Banni, S., Melis, M., Crnjar, R., \& Barbarossa, I. T. (2014). Genetic Sensitivity to the Bitter Taste of 6-n-Propylthiouracil (PROP) and Its Association with Physiological Mechanisms Controlling Body Mass Index (BMI). Nutrients, 6(9), 3363-3381.

Timpson, N. J., Christensen, M., Lawlor, D. A., Gaunt, T. R., Day, I. N., Ebrahim, S. D., \& Smith, G. (2005). TAS2R38 (phenylthiocarbamide) haplotypes, coronary heart disease traits, and eating behavior in the British Women's Heart and Health Study. Am. J. Clin. Nutr, 81, 1005-1011.

Tran, H. T. T., Herz, C., Ruf, P., Stetter, R., \& Lamy, E. (2018). Human T2R38 Bitter Taste Receptor Expression in Resting and Activated Lymphocytes. Front Immunol., 9, 29-49.

Turner-McGrievy, G. F., Tate, D., \& Moore, D. (2013). Taking the bitter with the sweet: Relationship of super tasting and sweet preference with metabolic syndrome and dietary intake. J Food Sci, 78(2), S336-S342.

Verbeurgt et al. (2017). The human bitter taste receptor T2R38 is broadly tuned for bacterial compounds. PLoS ONE, 12(9), e0181302.

Viswanathan, V. K. (2013). Sensing bacteria, without bitterness? Gut Microbes, 4(2), 91-93. Landes Bioscience.

Wang et al. (2010). Genes and their effects on dental caries may differ between primary and permanent dentitions. Caries Res, 44, 277-84.

Weber, M. L. (2016). Examining the relationship between the genotype and redefined phenotype of dental caries. $\mathrm{PhD}$ Thesis, University of Pittsburgh.

Weber, M., BogstadSøvik, J., Mulic, A., Deeley, K., ..., \& Vieira, A. R. (2018). Redefining the Phenotype of Dental Caries. Caries Res, 52(4), 263-271. 
Wendell, S., Wang, X., Brown, M., Cooper, M. E., ..., \& Marazita, M. L. (2010). Taste genes associated with dental caries. J Dent Res, 89(11), 1198-1202.

WHO. (2003). The World Health Organization. The World Oral Health Report 2003.

WHO. (2017). The World Health Organization. Global strategy on diet, physical activity and health dental diseases and oral health.

Wölfle, U., Elsholz, F. A., Kersten, A., Haarhaus, B., Müller, W. E., \& Schempp, C. M. (2015). Expression and functional activity of the bitter taste receptors TAS2R1 and TAS2R38 in human keratinocytes. Skin Pharmacol Physiol., 28(3), 137-46.

Wooding, S., Bufe, B., Grassi, C., Howard, M. T., ..., \& Bamshad, M. J. (2006). Independent evolution of bitter-taste sensitivity in humans and chimpanzees. Nature, 440(7086), 930-4.

Wooding, S., Kim, U. K., Bamshad, M. J., Larsen, J., Jord, L., \& Drayan, D. (2004). Natural selection and olecular evolution in PTC bitter-taster receptor gene. Am. J. Hum. Genet, 74, 637- 646.

Yamaki, M., Saito, H., Isono, K., Goto, T., ..., \& Komai, M. (2017). Genotyping Analysis of Bitter-Taste Receptor Genes TAS2R38 and TAS2R46 in Japanese Patients with Gastrointestinal Cancers. J Nutr Sci Vitaminol., 63, 148-154.

Yildiz, G., Ermis, R. B., Calapoglu, N. S., Celik, E. U., \& Turel, G. Y. (2016). Gene-environment Interactions in the Etiology of Dental Caries. J. Dent. Res, 95, 74-79.

\section{Copyrights}

Copyright for this article is retained by the author(s), with first publication rights granted to the journal.

This is an open-access article distributed under the terms and conditions of the Creative Commons Attribution license (http://creativecommons.org/licenses/by/4.0/). 